\title{
Hunian Vertikal Kontainer Buruh Pt Kima Dengan Konsep Arsitektur Humanis
}

\author{
Liza Utami Marzaman ${ }^{1}$, Amiruddin Akbar Fisu² \\ ${ }^{1}$ Program Studi Arsitektur, Universitas Hasanuddin, Makassar \\ ${ }^{2}$ Program Studi Teknik Sipil, Universitas Andi Djemma, Palopo \\ E-mail: ${ }^{1}$ icamarz@gmail.com, ${ }^{2}$ amiruddinakbarfisu07@gmail.com
}

\begin{abstract}
Abstrak
Tujuan penelitian ini adalah untuk mendesain Rumah Susun yang layak huni bagi Buruh PT KIMA Makassar melalui pendekatan yang humanis, sejalan dengan kebutuhan kaum buruh sehari-hari untuk beristirahat, sekaligus memaksimalkan potensi perancangan tapak yang menunjang interaksi sosial dan rekreasi. Pemilihan lokasi Rumah Susun berada di dalam kawasan PT KIMA yang dapat Kata kunci ditempuh berjalan kaki sehingga dapat menunjang produktivitas kerja serta memberikan waktu lebih Rumah susun; banyak untuk berinteraksi dengan keluarga. Material yang digunakan adalah kontainer bekas sebab Container; $\quad$ ketersediaannya yang cukup banyak dan kemudahan dalam proses pembangunannya serta memiliki

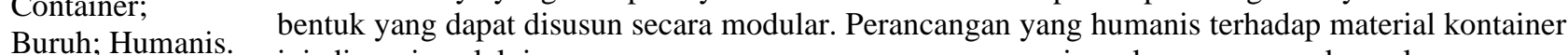
ini dicapai melalui perancangan ruang-ruang yang menunjang kenyamanan akses, kenyamanan termal, dan interaksi sosial. Massa bangunan ditata agar mampu memaksimalkan pengkondisian iklim mikro secara alami. Pada unit-unitnya dirancang dengan memaksimalkan bukaan untuk pencahayaan dan penghawaan alami, serta dengan sistem insulasi menggunakan material glass wool. Ruang-ruang diatur agar memungkinkan interaksi sosial. Ruang-ruang terbuka dan komunal dioptimalkan, seperti pada area selasar dan taman-taman di dalam tapak.
\end{abstract}

\begin{abstract}
The purpose of this research is to design a decent housing for PT KIMA Makassar laborers through a humanistic approach, in line with the needs of the daily laborers to rest, while maximizing the potential of site design that supports social interaction and recreation. The selection of flats location

Keywords is within PT KIMA area which can be reached on foot so that it can support work productivity and

Flats;

Containers;

Laborers; give more time to interact with family. The material used is used shipping container because of its considerable availability and ease of construction process as well as has a form that can be arranged in modular. The humanist design of the container material is achieved through the design of spaces

Humanistic. that facilitate access comfort, thermal comfort, and social interaction. Building masses are designed to maximize microclimate conditioning naturally. The units are designed to maximize openings for natural lighting and cross ventilation, as well as with insulation systems using glass wool material. Spaces are arranged to allow for social interaction. The open and communal spaces are optimized, as in the lobby area and the gardens within the site.
\end{abstract}

\section{PENDAHULUAN}

Berkembangnya Kota Makassar menuju Metropolitan Maminasata (Makassar, Maros, Sungguminasa, dan Takalar) yang mendorong dibangun dan dikembangkannya beberapa kawasan industri seperti KIMA, KIROS, KIMAWA, KIWA, dan KITA (Wunas et al. 2015), menyebabkan permintaan terhadap pekerja atau dalam hal ini buruh semakin meningkat. Kaum buruh yang bekerja di pabrik-pabrik PT KIMA sendiri, berasal dari berbagai daerah dari dalam dan luar provinsi Sulawesi Selatan, dengan tujuan untuk mendapatkan penghasilan dan penghidupan yang lebih baik.

Berdasarkan data yang didapatkan melalui wawancara singkat dengan pengelola PT KIMA, terdapat sekitar 15.000 orang karyawan/ buruh pabrik yang bekerja di dalam kawasan PT KIMA. Saat ini, telah terdapat 692 unit satuan rumah susun (Sarusun) yang telah menampung kurang lebih 2000 orang pekerja PT KIMA, namun masih terdapat lebih dari 10.000 orang pekerja yang masih bermukim di luar kawasan dan harus berjalan kaki atau mengendarai kendaraan umum/pribadi menuju dan pulang dari tempat mereka bekerja setiap harinya

Dengan mempertimbangkan pokok kebijakan pembangunan rumah susun sederhana sebagai prioritas dengan arah kebijakan untuk memenuhi kebutuhan akan tempat tinggal bagi masyarakat berpenghasilan 
menengah ke bawah dengan harga yang terjangkau (PERMEN PU No.5/ 2007), maka bangunan hunian untuk buruh PT KIMA juga akan mengadopsi bentukan rumah susun (rusun) yang juga mampu mengatasi masalah kelangkaan lahan di kota. Pembangunan hunian vertical merupakan salah satu bentuk optimalisasi fungsi lahan permukiman yang terbatas (Fisu 2016). Selain itu, pembangunan rusun juga dapat mengurangi penutupan lahan hijau sehingga pembangunan rumah susun untuk buruh ini dapat memberi kontribusi yang baik pula untuk lingkungan disekitarnya yaitu dengan menyediakan lahan resapan yang lebih luas (Mariana 2014).

Perkembangan teknologi bangunan saat ini semakin pesat, dengan adanya hal ini arsitek dituntut untuk lebih kreatif dalam memilih dan memilah bahan material bangunan bekas untuk digunakan kembali (Septianto et al. 2015). Kontainer bekas yang terbengkalai di tempat seperti pelabuhan, karena biaya yang tinggi untuk mengembalikan ke tempat asal. Maka muncul pemikiran bahwa kontainer bekas dapat digunakan sebagai sesuatu yang bermanfaat, salah satunya adalah sebagai bangunan (Nadia \& Carissa 2019). Peti kemas memiliki modul yang sama persis, mudah dirangkai, jumlahnya yang banyak dan harga yang murah dapat menjadi inovasi baru sebagai ruang hunian manusia dengan penanganan yang benar dan penerapan ilmu kenyamanan thermal dalam bangunan. (Fitrianto et al. 2017). Desain konstruksi dan struktur kontainer mempermudahkan mobilitas pengangkutannya, sehingga memungkinkan pemindahan barang antar sarana transportasi tanpa harus membongkar isi muatan terlebih dahulu. (Prajogo \& Tedjokoesoemo 2015). Selain itu, bahan container mudah dimobilisasi, mudah dirakit dan dibongkar sehingga memungkinkan prefabrikasi yang lebih ramah lingkungan (Haq et al. 2017).

Beberapa hal yang bisa menjadi bahan pertimbangan dari penggunaan kontainer bekas adalah biaya yang murah, mudah diangkut dan dimodifikasi, kekuatan materi yang sudah diuji, tahan gempa/bencana serta meminimalisir resiko terhadap bencana (Mahira \& Higmasari 2018). Pemilihan material kontainer bekas menjadi salah satu alternatif untuk mempercepat proses pembangunan karena memiliki bentuk yang dapat disusun secara modular. Namun, bukan berarti penggunaan material kontainer bekas khususnya pada wilayah dengan iklim tropis seperti di Makassar tidak memiliki sisi yang negatif. Perancangan rumah susun buruh PT KIMA ini dilakukan dengan memaksimalkan potensi kontainer bekas, sebagai alternatif material yang relatif murah, mudah, dan cepat dalam pembangunan.

Kehidupan kaum buruh yang dekat dengan kerja keras dan rutinitas yang hampir sama setiap harinya menyebabkan timbulnya kejenuhan dan stres selama di tempat kerja (Nandini et al. 2019). menyatakan kondisi phycological wellbeing, atau kondisi emosi kebahagiaan subjektif individu, sangat mempengaruhi kepuasan kerja dan kesehatan fisik buruh. Hal-hal yang dipengaruhi diantaranya kondisi imun, pengambilan keputusan dalam menjaga kesehatan serta motivasi dalam menjalankan pekerjaan (Salovey, Rothman, Detweiler \& Steward, 2000; Faragher, Cass \& Cooper, 2005 dalam Nandini et al. 2019).

Hal ini berkaitan erat dengan konsep perancangan arsitektur yang humanis terhadap hunian susun buruh yang akan dicapai melalui terpenuhinya pesyaratan fisik/ non fisik meliputi aspek keselamatan, kesehatan, kenyamanan dan kemudahan dalam bangunan dan lingkungannya (Sabaruddin 2018) sehingga dapat tercipta kondisi phycological wellbeing bagi kaum buruh yang dapat dimulai dari tempat tinggal mereka.

Mengacu pada Standar Perencanaan Lingkungan Perumahan di Perkotaan, kriteria kenyamanan dapat dicapai dengan kemudahan pencapaian (aksesibilitas), kemudahan berkomunikasi (internal/eksternal, langsung atau tidak langsung), kemudahan berkegiatan (prasarana dan sarana lingkungan tersedia). Pembangunan rusun direncanakan pada lokasi dengan aksesibilitas yang tinggi ke tempat kerja. Menurut Fisu (2016), radius 400 meter merupakan jarak yang masih tergolong nyaman untuk berjalan kaki.

Oleh karenanya, aspek kemudahan akses menjadi salah satu poin penting dalam perancangan rumah susun buruh yang nyaman dan lebih humanis. Aksesibilitas yang tinggi dapat meningkatkan produktivitas industri dengan menjadikan jarak rumah susun buruh lebih dekat dengan tempat kerjanya, menghemat biaya transportasi dan waktu tempuh menuju dan pulang dari tempat kerja sehingga dapat segera beristirahat dan berkumpul dengan keluarga.

Di sisi lain, aspek-aspek fisik dalam perancangan rumah susun buruh yang nyaman dan berkualitas juga tidak dapat diabaikan. Aspek fisik-teknis tersebut meliputi teknologi bahan dan struktur yang dipilih, sistem utilitas, serta kualitas ruang yang mencakup kenyamanan termal, yang ditunjang oleh sirkulasi udara dan angin yang baik (Sabaruddin 2018). Kota Makassar terbilang cukup panas dengan karakteristik iklim meliputi kelembaban udara rata-rata yang cukup tinggi yaitu sebesar 84,7 persen, temperatur rata-rata berkisar antara $26,8-28,4^{\circ} \mathrm{C}$, dan kecepatan angin rata-rata 5,3 knot. Faktor-faktor iklim tersebut akan sangat mempengaruhi kondisi kenyamanan di dalam sebuah bangunan kontainer yang terbuat dari material besi/baja.

Kenyamanan termal di daerah iklim tropis lembab, memiliki rentang suhu antara $24-30^{\circ} \mathrm{C}$ yang dianggap nyaman bagi manusia yang berdiam pada daerah iklim tersebut. Dikatakan lagi dalam jurnal yang sama, bahwa capaian minimum untuk kenyamanan termal ruang dalam bagi orang Indonesia adalah berada di bawah $28,3^{\circ} \mathrm{C}$, 
ketika suhu udara di luar ruangan berkisar pada $32^{\circ} \mathrm{C}$. Kurniasih (2019) menggolongkan iklim Indonesia pada umumnya berupa panas-lembab dimana adaptasi terhadap jenis iklim ini dicontohkan pada rumah-rumah tradisional Nusantara yang sebagian besar berpanggung. Kolong pada rumah panggung tradisional dinilai berfungsi untuk mengalirkan udara di dalam tapak serta mengeliminasi kelembapan di sekitar bangunan yang dihasilkan oleh tanah.

Pada perancangan ini pencapaian kenyamanan termal akan dilakukan melalui pendekatan pasif yaitu dengan memaksimalkan sistem ventilasi silang yang didukung oleh perancangan ruang luar yang mampu menurunkan suhu luar ruangan secara alami. Adapun pendekatan yang dilakukan yaitu melalui:

a. Memaksimalkan peran vegetasi di dalam tapak, dengan tidak menebang terlalu banyak pohon eksisting, dan menanam lebih banyak pohon peneduh yang akan berfungsi sebagai filter radiasi matahari agar tidak langsung menerpa sisi-sisi bangunan. Menurut Irwan, dalam Mala (2018), daun-daun vegetasi mampu menghalangi dan menyaring cahaya matahari, serta ranting-ranting membantu dalam mengatur kecepatan angin dan laju curah hujan di sekitar daerah yang dinaunginya. Selain itu, Pepohonan juga berfungsi untuk tempat berteduh, dan meredam kebisingan serta menfilter udara menjadi lebih segar dan bersih (Hidayat dan Fisu 2019). Selain itu, vegetasi juga merupakan prinsip konsep penataan lingkungan dengan memanfaatkan sumberdaya alam yang ada dan penggunaan teknologi secara etis untuk mendapatkan desain Arsitektur yang ramah Lingkungan (Prasetyo et al. 2018)

b. Membuat dinding berlapis dengan ventilasi/rongga di antaranya, atau menambahkan material insulasi pada dinding dan atap.

c. Memaksimalkan bukaan pada posisi yang tepat di sisi-sisi bangunan untuk memaksimalkan ventilasi silang (cross ventilation) yang dapat menghasilkan aliran udara alami di dalam bangunan.

d. Membuat struktur berpanggung pada tiap tower unit rusun untuk memaksimalkan aliran udara di dalam tapak dan mengurangi terjadinya kelembaban di sekitar bangunan.

Selanjutnya, interaksi sosial akan menjadi fokus terakhir dari perancangan rumah susun yang humanis ini. Kebutuhan sosial (social needs), adalah satu dari lima kebutuhan utama yang digambarkan Abraham Maslow tentang hierarki kebutuhan manusia. Kebutuhan sosial diartikan sebagai kebutuhan manusia akan rasa memiliki dan dimiliki, kasih sayang, dan persahabatan. Pada perancangan rumah susun buruh PT KIMA ini akan menyediakan ruang-ruang sosial dan rekreasi seperti taman-taman, area bermain untuk anak-anak, lapangan olahraga, juga selasar dengan tempat-tempat duduk.

\section{METODE PENELITIAN}

Survei dilakukan untuk mengetahui dan mengumpulkan data-data kondisi alternatif lokasi yang nantinya akan dianalisis, antara lain sirkulasi, kondisi vegetasi, jarak-jarak berjalan kaki, serta fasilitas umum yang tersedia.

Karena bersifat sebagai konsep perencanaan, maka analisis yang digunakan lebih menggunakan kajian pustaka, yaitu dengan mengumpulkan pustaka untuk dipelajari dan mendapatkan data beserta informasi yang dibutuhkan dan relevan dengan penelitian ini. Adapun analisis yang digunakan, adalah analisis pembobotan untuk penentuan alternatif lokasi terpilih.

Proses perancangan konsep dilakukan dengan menyesuaikan kondisi tapak, referensi dan standar yang telah dikumpulkan, dan inovasi penulis.

\section{HASIL DAN PEMBAHASAN}

Hasil dari perancangan ini adalah tentang transformasi konsep humanis pada fisik rumah susun kontainer buruh PT KIMA, yang dapat dicapai melalui beberapa konsep atau pendekatan perancangan yaitu:

a. Konsep penentuan lokasi

b. Konsep perancangan dan pengondisian tapak

c. Konsep penataan massa, ruang, dan sirkulasi

d. Konsep material dan bentuk bangunan

e. Konsep pengondisian ruang dalam kontainer

Konsep yang diterapkan, mulai dari penentuan lokasi, perancangan pengondisian tapak, penataan massa, ruang, dan sirkulasi, material, bentuk, hingga pengondisian ruang dalam kontainer bertujuan agar bangunan kontainer yang dihasilkan dapat menjadi nyaman dan lebih humanis untuk dihuni. Selain itu, interaksi antar manusia dan dengan alam sekitar juga dirancang untuk meluweskan suasana dan mereduksi stress bagi kaum buruh PT KIMA.

\section{Konsep Penentuan Lokasi}


Kawasan PT KIMA telah didukung oleh jaringan transportasi yang baik, yaitu akses utama melalui Jalan Perintis Kemerdekaan dan jalan Tol Sutami. Luas seluruh lahan PT KIMA yaitu 310 HA dimana telah dilengkapi denga prasarana jalan seluas 32,5 HA dan kawasan pergudangan seluas 5,3 HA.

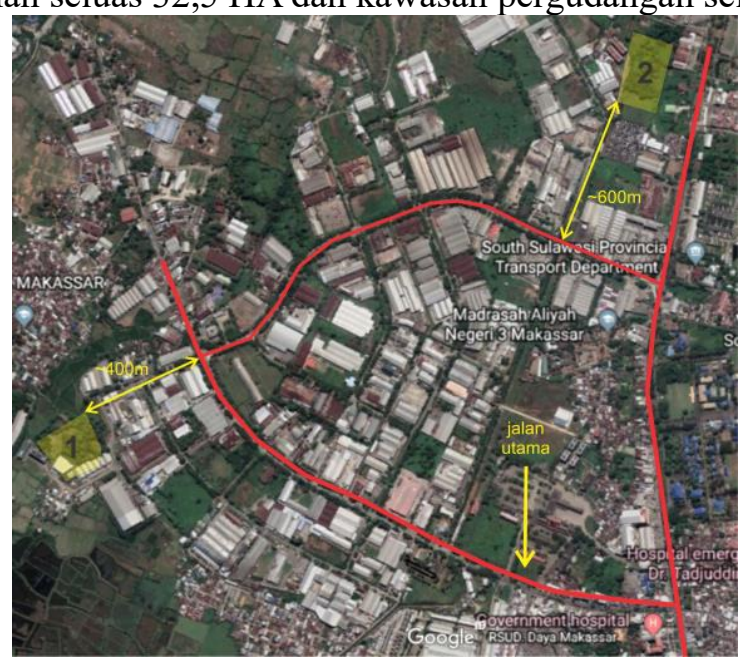

Gambar 1. Alternatif 1 dan 2 Tapak

Secara umum, semakin dekat hunian dengan tempat kerja, semakin baik. Demikian pula kebutuhan untuk terlindungi dari berbagai macam polusi termasuk polusi udara dan kebisingan yang dapat didukung oleh adanya pengondisian vegetasi eksisting.

Berdasarkan penelitian yang dilakukan oleh Herman et al. (2016), tentang preferensi bermukim tenaga kerja Kawasan Industri Makassar menyatakan dari 23,7 persen pekerja yang bermukim dengan status sewa memilih pindah ke rusun yang berada di dalam kawasan industri dengan alasan jarak yang lebih dekat dan harga sewa yang lebih terjangkau. Jarak yang dikehendaki adalah minimal kurang dari 1-3 kilometer. Adapun 51,9 persen penghuni rusun yang ada menyatakan merasa betah karena jarak yang dekat dengan tempat kerja, biaya sewa yang murah, serta didukung oleh kondisi hunian yang memadai.

Dalam jurnal yang sama, faktor kenyamanan juga menyumbang 44 persen preferensi untuk memilih tinggal di dalam kawasan meskipun jarak dengan tempat kerja berdekatan dengan hunian. Semetara faktor 'ketenangan' lokasi lebih berperan dalam menunjang kenyamanan daripada faktor hunian yang lengkap dan memadai.

Dari kriteria tersebut, didapatkan alternatif lokasi 1 dan 2 (Gambar 1), yang akan diseleksi melalui beberapa kriteria pemilihan tapak, yaitu:

a. Merupakan lahan kosong yang terletak di dalam kawasan PT KIMA (Makassar); Tapak terpilih harus berupa lahan yang belum terbangun di dalam Kawasan PT KIMA sehingga tidak dibutuhkan energi yang banyak untuk pembersihan tapak serta dapat memanfaatkan sebesar-besarnya potensi alami tapak, seperti kontur dan vegetasi.

b. Terdapat fasilitas dengan fungsi industri/ gudang yang maksimal berjarak 400 meter dari tapak; Tapak yang baik adalah yang berjarak kurang dari 400 meter dari lokasi tempat buruh bekerja sehingga dapat dijangkau dengan berjalan kaki (Fisu 2016).

c. Didukung oleh prasarana jalan, saluran drainase, air bersih, listrik dan telekomunikasi yang memadai; Mengacu pada Standar Perencanaan Lingkungan Perumahan di Perkotaan, perumahan yang baik harus didukung oleh sarana dan prasarana kota yang baik dan menunjang keberlangsungan tapak.

d. Mendukung kebutuhan akan privasi hunian: dekat dengan jalan utama namun tidak terlalu dekat dengan bangunan pabrik yang bising; Privasi dibutuhkan sebab fungsi bangunan yang diinginkan adalah hunian, dimana kenyamanan akan privasi dan ketenangan (Herman et al., 2016) mendukung konsep humanis pada perancangan ini.

e. Memiliki eksisting vegetasi/pepohonan yang cukup banyak untuk meredam polusi udara dan suara, serta memberi teduhan, suplai oksigen, dan tutupan privasi.

Tabel 1. Pembobotan Pemilihan Tapak

\begin{tabular}{clcc}
\hline No. & \multicolumn{1}{c}{ Kriteria } & Alt.1 & Alt.2 \\
\hline 1. & $\begin{array}{l}\text { Berupa lahan kosong di } \\
\text { dalam kawasan PT. }\end{array}$ & 4 & 4 \\
& & \\
\hline
\end{tabular}


2. Berada pada radius 400 $\mathrm{m}$ dari tempat kerja (Fisu, 2016)

3. Didukung oleh prasarana yang memadai

4. Sekeliling tapak tidak didominasi oleh pabrik (tenang, tidak bising)

5. Memiliki pohon eksisting yang cukup banyak (buffer panas \& polusi)
4

4

$4 \quad 3$

$4 \quad 4$

$4 \quad 3$

4

$20 \quad 18$

Dari tabel analisis pembotoan, diperoleh tapak terpilih adalah tapak alternatif 1 yang berlokasi di Jalan Kima 10, dengan luasan $+/-19.000 \mathrm{~m}^{2}$, dengan radius berjalan kaki 150-500 meter menuju tempat kerja yaitu bangunan pabrik dan gudang. Tapak ini telah dilengkapi dengan akses yang baik berupa jalan paving selebar $3 \mathrm{~m}$. Lahan tersebut juga terletak cukup privat dan jauh dari kebisingan pabrik serta didukung pula dengan eksisting vegetasi yang mampu menghalau radiasi matahari, menangkap angin, serta menyaring polusi udara dan suara. Tapak terpilih ini juga terletak dekat dengan kawasan permukiman penduduk di sekitar wilayah KIMA, sehingga telah ditunjang oleh jaringan utilitas kota seperti listrik, air bersih, dan telepon.

Orientasi tapak terhadap akses utama menghadap ke arah Timur. Arah angin dominan datang dari arah Utara. Pepohonan di dalam tapak membantu menangkap angin tetap dan memberi shading yang cukup menghalau panas dari arah Timur-Barat.

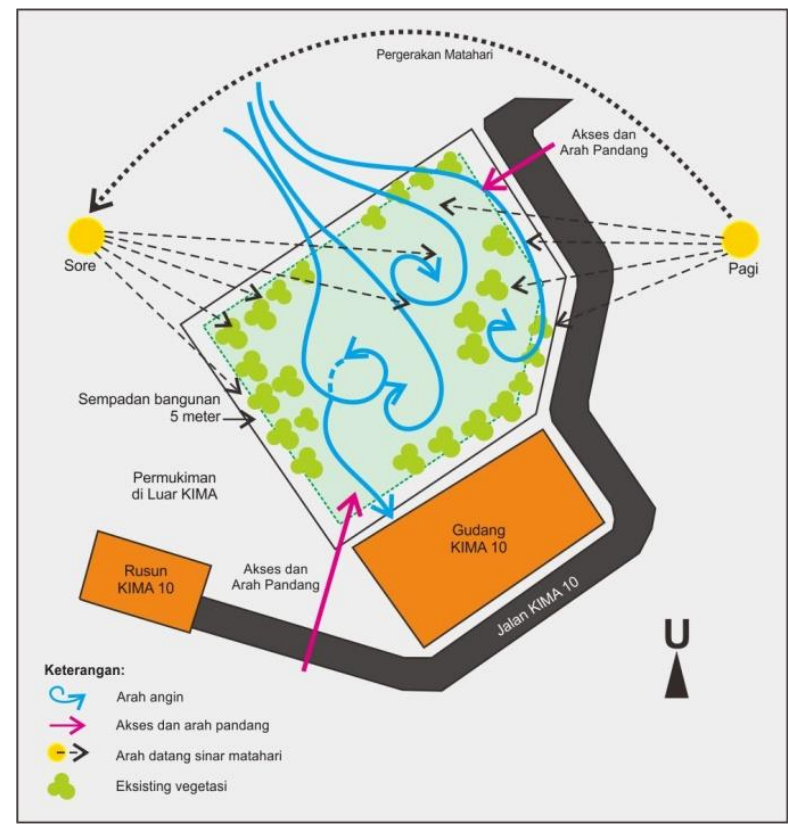

Gambar 2. Kondisi Eksisting Tapak

\section{Konsep Perancangan dan Pengondisian Tapak}

Menaggapi kondisi eksisting tapak, perletakan hunian diupayakan berada pada area yang bersifat privat dan jauh dari kebisingan, yaitu pada sisi Utara, sudut Barat dan Selatan dari tapak (Gambar 3). Area tersebut terletak pada sisi terjauh dari jalan utama yang dilalui kendaraan. Selain itu, area tersebut juga dikelilingi oleh pohon-pohon peneduh eksisting yang dapat menghalau radiasi matahari utamanya dari arah Barat pada sore hari.

Menurut Latifah (2018), untuk memaksimalkan aliran udara/angin pada bangunan setidaknya posisi arah angin tegak lurus dengan arah bukaan pada bangunan. Reduksi kecepatan gerak angin terjadi sesuai dengan kemiringan arah angin terhdap bukaan dan belokan yang terjadi di dalam tapak. Oleh karenanya, orientasi bangunan rumah susun sedapatnya mengikuti arah Utara-Selatan yang akan disesuaikan dengan perletakan 
selasar dan bukaan seperti jendela atau jalusi pada area balkon.

Bangunan-bangunan di dalam tapak akan mengelilingi sebuah ruang terbuka di tengah-tengah tapak yang berfungsi sebagai area tangkapan angin yang akan membantu mendinginkan iklim luar bangunan (tapak). Pada lahan tersebut, akan dibanguni taman-taman, area bermain, dan lapangan olahraga. Sedangkan area publik seperti kantor pengelola akan ditempatkan pada titik yang terdekat dengan jalan atau akses masuk yaitu pada sisi Timur dari tapak.

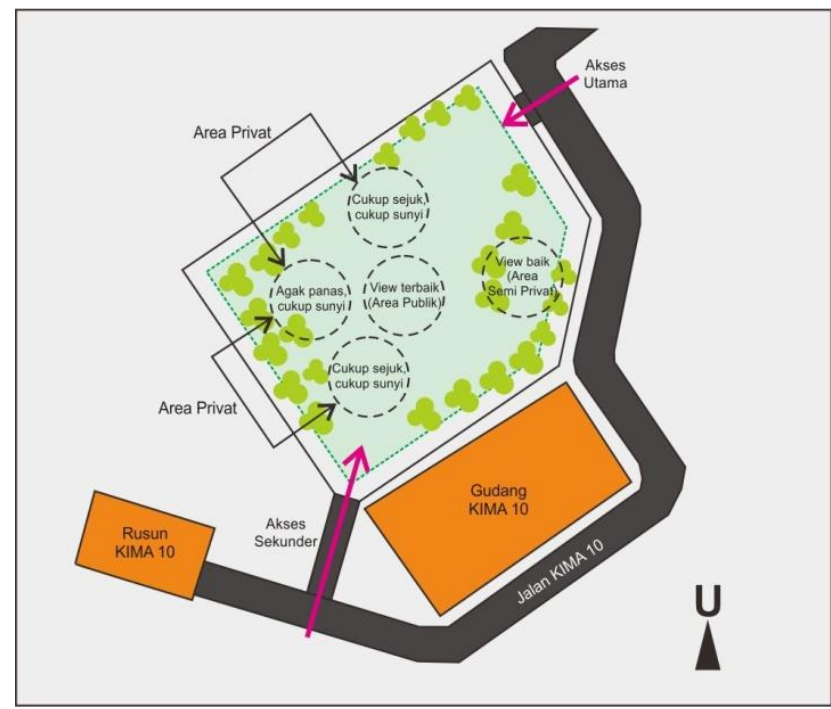

Gambar 3. Tanggapan Terhadap Kondisi Eksisting Tapak

Akses utama diletakkan pada sisi Timur berdekatan dengan jalan utama di luar tapak. Sementara akses sekunder diletakkan pada sudut Tenggara yang menghubungkan dengan area permukiman buruh lainnya di sekitar tapak.

\section{Konsep Penataan Massa, Ruang, dan Sirkulasi}

Konsep penataan massa dalam tapak mengikuti pola sirkulasi radial untuk memudahkan pencapaian fasilitas publik dari area hunian dan servis di sekelilingnya (Gambar 4). Jalan masuk utama diletakkan pada sisi Timur, dan jalan masuk sekunder berada pada sebelah Tenggara.

Fasilitas publik yang akan disediakan berupa, ruang pertemuan, musholla, taman-taman yang dilengkapi area refleksi, area rumput yang serbaguna misalnya untuk berekreasi, berolahraga dan bermain untuk anakanak. Ruang-ruang terbuka juga akan menjadi area pertukaran udara di antara bangunan, sehingga menunjang iklim yang nyaman bagi penghuni, serta menambah nilai keindaan dan estetika dari lingkungan rusun.

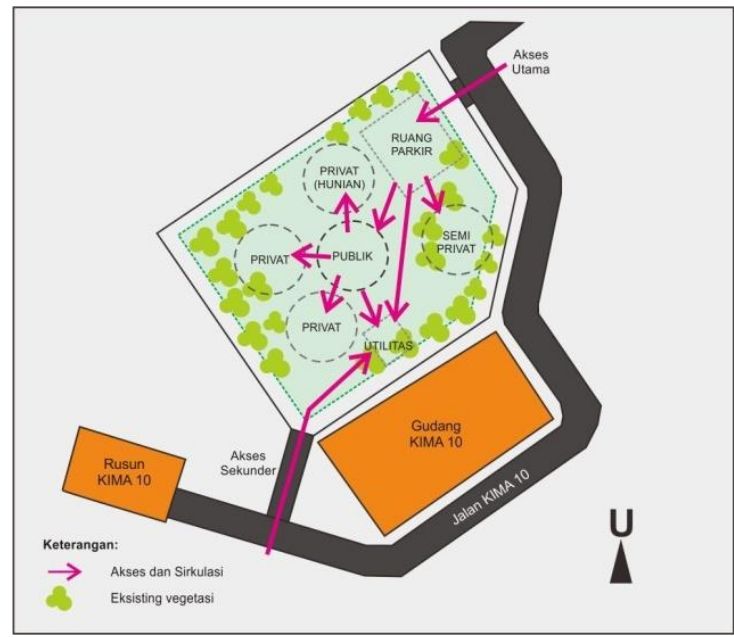

Gambar 4. Pengaturan Massa, Ruang dan Sirkulasi

\section{Konsep Bentuk, Material dan Struktur Bangunan}

Material utama yang digunakan pada perancangan rumah susun ini adalah kontainer bekas. Penggunaan material kontainer sudah cukup lazim digunakan pada beberapa karya arsitektur baik di luar dan di dalam 
negeri. Hal tersebut disebabkan karena potensi yang dimiliki kontainer berupa potensi modular yang dapat memungkinkan proses pembangunan berlangsung lebih singkat dibandingkan dengan proses konvensional. Selain itu, struktur bawaan dari kontainer dapat mengurangi penggunaan material konvensional seperti batu bata, besi, dan beton, sehingga tidak meninggalkan limbah konstruksi yang berlebihan (Kamarazaly et al., 2017).

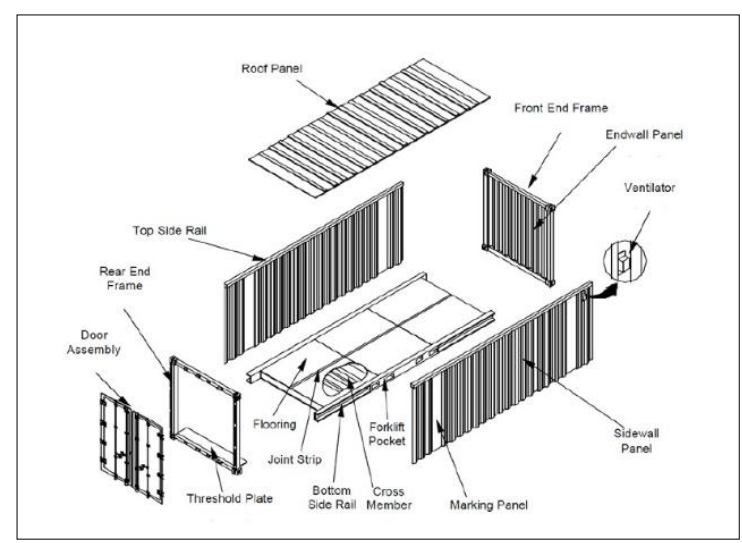

Gambar 5. Ilustrasi Bagian-Bagian Sebuah Kontainer, (Sumber: Kamarazaly et al., 2017)

Penggunaan container sebagai hunian hanya dapat dilakukan pada material yang masih memiliki kualitas yang layak pakai baik secara fisik maupun materi. Namun, dengan pengalihan fungsi dari material semula, proses tidak memberikan fleksibilitas dalam desain karena keterbatasan bentuk yang diberikan oleh material lama (Kumara \& Kusumarini 2015).

Jenis kontainer yang digunakan pada unit rumah susun ini adalah jenis kontainer berstandardisasi ISO 20' High Cube (HC) yang memiliki tinggi kurang lebih 8'9"' (2,896 meter), lebih 1' (0,3048 meter) dari kontainer biasanya. Penggunaan jenis High Cube diutamakan karena memungkinkan ruang utilitas seperti ruang ducting, plumbing, dan elektrikal dibuat pada area langit-langit di tiap unit hunian, dan pada saat yang bersamaan juga menyediakan ruang yang dapat dihuni di bawah langit-langit setinggi 2,40 meter (Bernardo et al. 2013), yang juga sejalan dengan standar ketinggian langit-langit minimum di Indonesia.

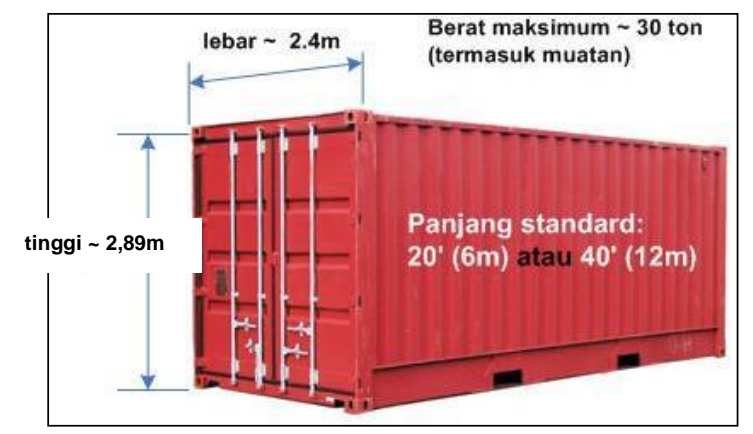

Gambar 6. Dimensi Kontainer,

(Sumber: Susanto, 2014)

Secara struktural, kontainer dengan modul 20 kaki dipilih karena memiliki konstruksi yang lebih kuat dibanding kontainer dengan modul 40 kaki (Ismail et al. 2015). Hal ini disebabkan karena jarak antar kolom terjauhnya lebih dekat, sehingga lebih kuat menahan beban vertikal dari atas. Selain itu, perletakan unit-unit kontainer 20 kaki dengan cara berderet dapat menambah kekuatan pada sisi yang berdempetan.

Secara tiga dimensional, massa kontainer disusun sedemikian rupa agar mampu mewadahi fungsinya, yaitu sebagai hunian. Selain itu, sedapat mungkin ruang yang terbentuk dari penyusunan massa container berupa ruang-ruang positif yang mampu mewadahi bebagai aktivitas utamanya interaksi sosial.

Material kontainer disusun sesederhana mungkin untuk mengefisienkan konstruksi yang dibutuhkan. Menurut Mazran Ismail et al. (2015), kontainer yang disusun vertikal sebaiknya bertumpu pada sisi atau axis yang sejajar untuk mempertahankan kekuatannya, serta untuk menahan gaya putar yang disebabkan oleh angin.

Adapun sistem konstruksi penopang kontainer yang digunakan adalah sistem konstruksi grid, kolom dan 
balok. Unit kontainer sudah memiliki sistem konstruksi sendiri yang terbuat dari balok baja yang cukup kuat untuk menopang beban di dalamnya.

Dua alternatif yang dikaji mempertimbangkan susunan yang dinamis untuk memaksimalkan pencahayaan alami dan sirkulasi udara di antara unit-unit kontainer. Selain itu, juga mengutamakan terbentuknya ruangruang positif di sela-sela unit sebagai tempat berinteraksi para penghuni rusun.

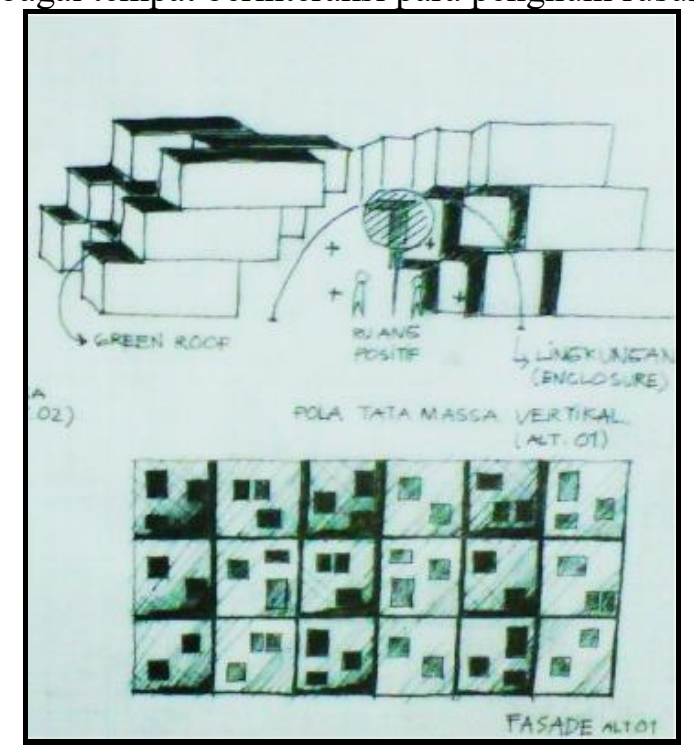

Gambar 7 Alternatif 1 Penataan Massa Unit Hunian

Alternatif pertama memungkinkan ruang-ruang interaksi yang luas dan nyaman, serta sirkulasi udara dan pertukaran cahaya yang optimal. Secara struktural alternatif pertama membutuhkan pengoganisasian yang cukup rumit, meskipun secara bersamaan memberikan bentuk yang dinamis dan tidak membosankan.

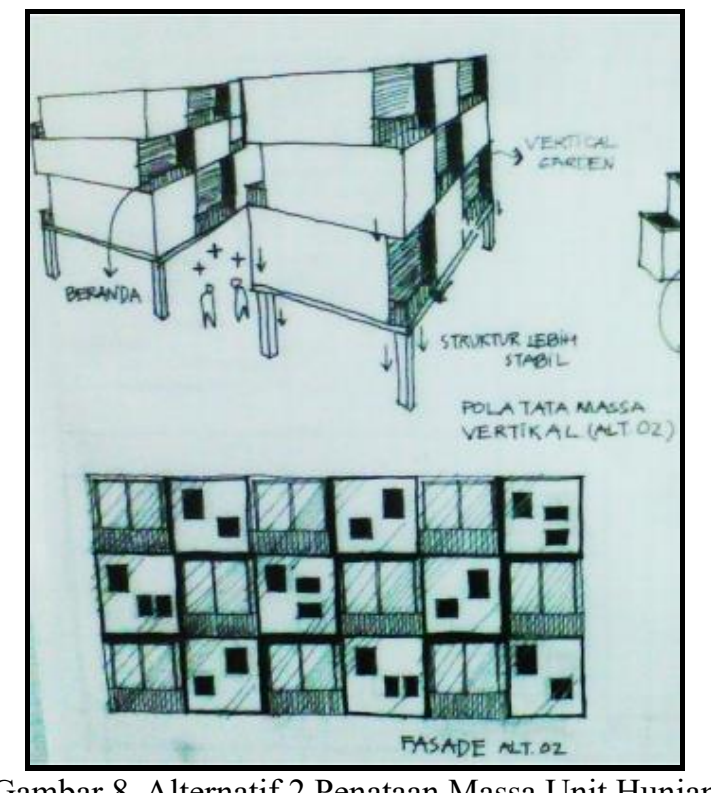

Gambar 8. Alternatif 2 Penataan Massa Unit Hunian

Alternatif kedua mencoba struktur yang lebih stabil dan sederhana. Dengan demikian, pengorganisasian massa kontainer secara vertikal terasa lebih aman. Meskipun pengaturan massa untuk mengoptimalkan pencahayaan dan sirkulasi udara alami tidak seoptimal aternatif pertama, namun dengan struktur yang lebih stabil, struktur berpanggung dapat diterapkan sehingga diperoleh ruang kolong yang dapat dimanfaatkan sebagai ruang bersama, dan juga berguna untuk sirkulasi udara di dalam tapak.

Alternatif penyususnan massa yang terpilih adalah alternatif 2 yang memiliki susunan massa yang lebih sederhana dan stabil. Selain itu, ritme yang dibentuk dapat memungkinkan sirkulasi udara yang baik ke dalam unit-unit kontainer (lihat Gambar 8). 
Struktur berpanggung dipilih sebab menunjang terbentuknya ruang-ruang positif di bawah kolong yang dapat berfungsi sebagai ruang parkir kendaraan penghuni (lihat Gambar 9). Selain itu, juga berperan dalam mengoptimalkan sirkulasi udara di dalam tapak serta mengurangi kelembaban (Kurniasih 2019).

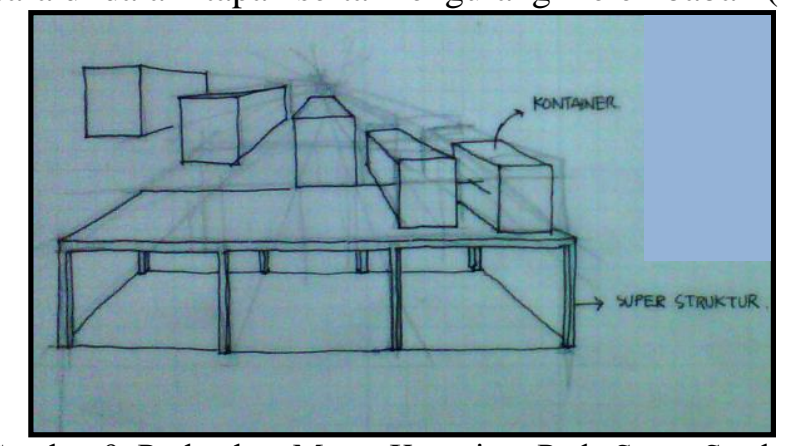

Gambar 9. Perletakan Massa Kontainer Pada Super Struktur

\section{Konsep Pengondisian Ruang Dalam Kontainer}

Kota Makassar yang memiliki iklim tropis dengan kelembaban udara rata-rata mencapai $70 \%$ dan suhu udara luar rata-rata sekitar $32,5^{\circ} \mathrm{C}$ sehingga menyebabkan pengondisian kenyamanan termal ruang dalam unit kontainer menjadi sangat penting. Secara umum, beberapa tahap yang dapat ditempuh untuk mendapatkan kenyamanan termal di dalam unit kontainer seperti yang disarankan oleh Susanto (2014), adalah sebagai berikut:

a. Mengupayakan jumlah dan jenis media pencahayaan serta luasan ventilasi pada suatu ruang sesuai dengan luas ruangan (terjadi keseimbangan/proporsional) yang akan diterangi dan diinginkan, serta menyesuaikan arah bukaan tersebut dengan orientasi bangunan yang sesuai.

b. Untuk menambah kenyamanan ruang juga bisa dilakukan penambahan jalusi pada dinding bagian atas di bawah atap. Hal ini akan sangat membantu reduksi udara panas yang masuk ke dalam ruang di bawah atap di atas plafond. Sehingga ruang didalamnya akan terasa sejuk dan nyaman.

c. Meminimalkan penggunaan fasilitas penyejuk udara, kipas angin, serta lampu pada siang hari dengan melakukan pengaturan serta pengolahan pencahayaan dan sirkulasi udara secara optimal misalnya dengan menggunakan dinding kaca, jalusi, maupun lubang angin/ventilasi.

Pengondisian unit-unit hunian kontainer untuk memungkinkan sirkulasi udara dan pencahayaan yang maksimal juga berkaitan erat dengan penataan massa unit-unit rusun kontainer. Hal tersebut mengingat bahwa pada bangunan rumah susun kontainer, tiap unitnya akan disusun bertumpuk dan berdempetan satu sama lain sehingga penataan yang baik dapat memungkinkan ruang untuk membuat bukaan-bukaan pada beberapa sisi kontainer sehingga pertukaran dan aliran udara dapat terjadi dengan lebih optimal.

Massa kontainer disusun secara zig-zag pada sumbu horizontal untuk memungkinkan adanya sisi yang bebas (tidak berdempetan) sebagai ruang untuk bukaan angin di tiap unit. Secara vertikal, susunan horizontal disusun dengan urutan yang berlawanan dengan susunan di bawahnya untuk memungkinkan tiap unit mendapat naungan dari unit di atasnya (Gambar 8).
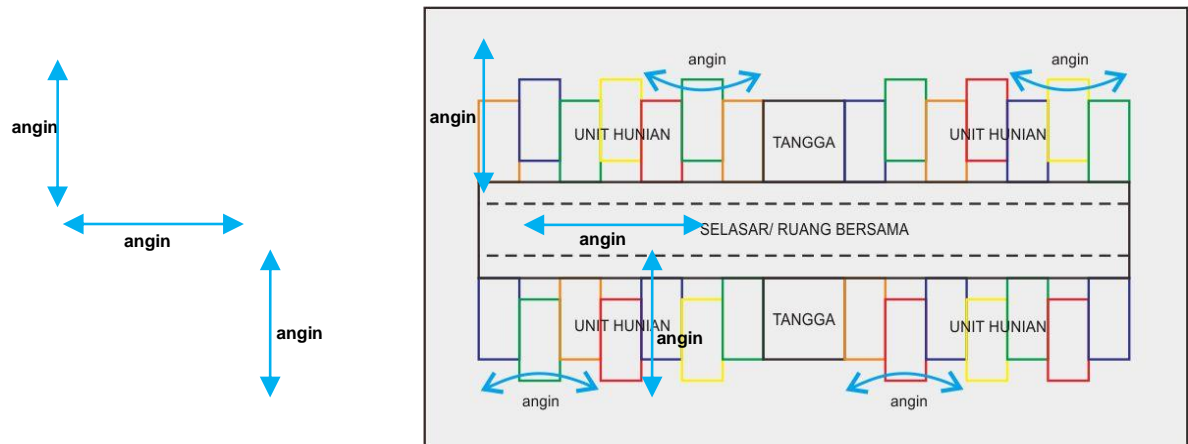

Gambar 10. Penataan Massa dan Pengaruhnya pada Sirkulasi Udara pada Unit Hunian

Dengan demikian, udara yang mengalir ke dalam unit akan membantu mengangkat uap air/kelembaban yang terbentuk dari proses kondensasi sehingga dapat tercipta kenyamanan di dalam ruangan. Untuk mempercepat pergerakan udara, perletakan alat seperti kipas exhaust (exhaust fan) pada titik-titik tertentu juga dapat berguna, selain juga masih cenderung terjangkau untuk masyarakat berpenghasilan rendah. 


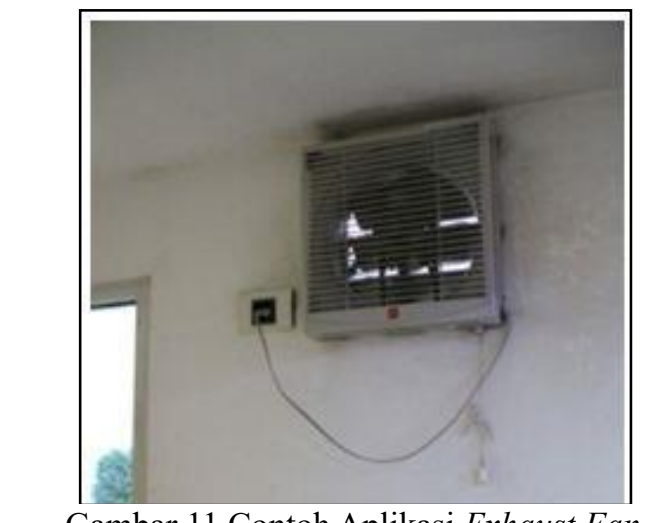

Gambar 11 Contoh Aplikasi Exhaust Fan
Memungkinkan Aliran Udara di Dalam Ruangan

(Sumber: Susanto, 2014)

Konstruksi kontainer yang terbuat dari $100 \%$ baja juga merupakan konduktor panas juga dapat meyebabkan terjadinya kondensasi/pengembunan di dalam ruangan sehingga ruangan menjadi lembab (Ismail, 2015). Oleh karena itu, sangat dibutuhkan penanganan yang lebih cermat melalui beberapa perlakuan terhadap unit kontainer untuk menciptakan suhu ruang dalam yang nyaman, khususnya bagi masyarakat menengah ke bawah yang cenderung tidak mampu membeli pendingin ruangan (AC).

Studi kelayakan huni bangunan kontainer yang dilakukan oleh Kamarazaly et al. (2017) menyebutkan, perlakuan terhadap material kontainer yang dianggap paling penting adalah tentang penginsulasian kontainer agar tercapai kenyamanan di dalam ruangannya. Material glass wool dapat menjadi salah satu alternatif insulator yang paling lazim digunakan pada dinding kontainer. Selain itu, untuk menambah efektivitas dari penginsulasian tersebut, dapat ditambahkan material vapor retarder.

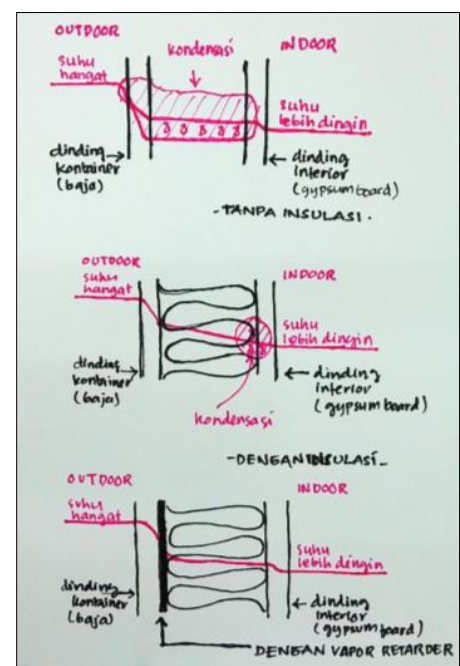

Gambar 12. Pengaplikasian Insulator dan Vapor Retarder untuk Mencegah Kondensasi Pada Dinding Bangunan

Material vapor retarder biasanya berupa lapisan plastik atau aluminum foil atau membran kedap air lainnya (Gambar 14) yang berfungsi untuk menghambat uap air memasuki buffer insulator (lapisan glass wool) (Gambar 13).

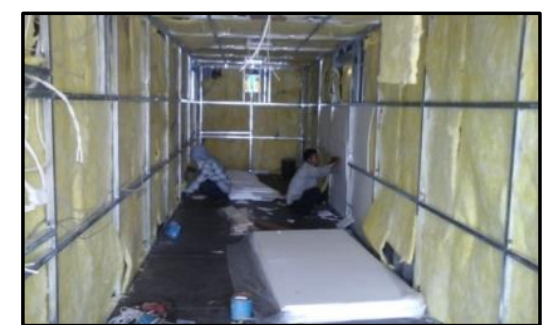

Gambar 13. Contoh Aplikasi Insulasi Menggunakan Glass Wool 


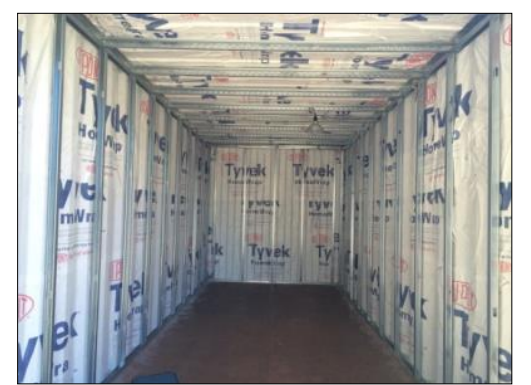

Gambar 14. Contoh Aplikasi Vapor Retarder pada Insulasi Dinding Kontainer

Untuk lapisan pada sisi interior, menggunakan papan gypsum yang juga memiliki daya peredam panas. Pada lantai, juga menggunakan insulasi lapisan glass wool yang berfungsi baik sebagai peredam panas maupun peredam suara, mengingat unit-unit kontainer akan disusun satu sama lain, sehingga suara dari unit yang terletak di atas dapat diredam dan tidak mengganggu pada unit di bawahnya.

Finishing lantai dapat ditutup dengan papan multipleks, atau papan fiber semen. Adapun pada atap, juga perlu dipikirkan dengan cermat mengingat atap pada unit paling atas juga berfungsi untuk melindungi bangunan dari terpaan hujan. Sehingga insulasi yang kedap air, seperti penambahan lapisan karet dapat dilakukan. Selain itu, penambahan struktur atap tambahan dengan kemiringan tertentu akan membantu mengalirkan air hujan dengan cepat sehingga tidak bersifat destruktif pada struktur unit kontainer.

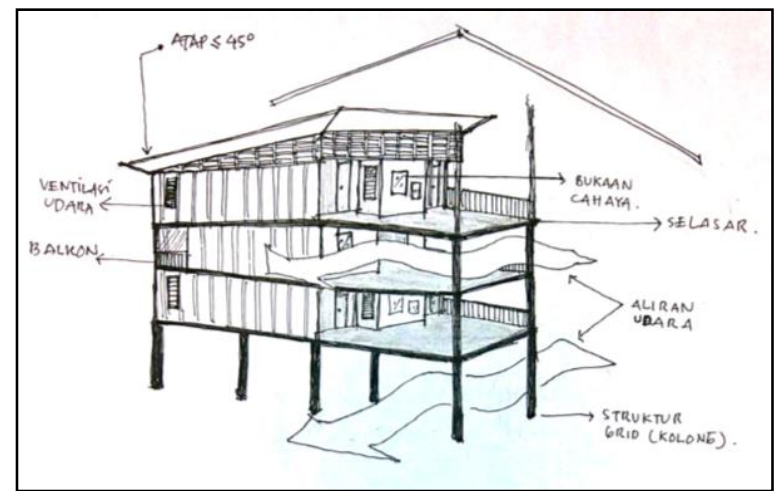

Gambar 15. Sketsa Output Desain Unit Hunian

Secara keseluruhan, rumah susun kontainer terlihat seperti pada Gambar 15. Area selasar, selain berfungsi sebagai ruang sirkulasi dan interaksi penghuni, juga sebagai ruang yang dialiri angin di sela-sela unit rusun. Susunan zig-zag massa kontainer menjadi ruang dimana ventilasi dan balkon tiap-tiap unit diletakkan.

\section{KESIMPULAN} yaitu:

Perwujudan rumah susun yang humanis bagi buruh PT Kima dapat dilakukan dengan beberapa pendekatan

1. Pemilihan lokasi yang berdekatan dengan tempat kerja, yaitu berada di dalam radius berjalan kaki (kurang dari 400 meter). Lokasi terpilih berada di dalam kawasan industri PT KIMA yang berlokasi di Jalan Kima 10, dengan luasan $+/-19.000 \mathrm{~m}^{2}$. Jarak lokasi tapak terhadap pergudangan/pabrik sekitar 150-500 meter sehingga masih tebilang humanis untuk berjalan kaki pergi dan pulang dari tempat kerja.

2. Pengolahan tapak melalui pendekatan pengondisian iklim pasif yang memperhatikan orientasi matahari, arah angin, dan memanfaatkan eksisting vegetasi sebagai pelindung cahaya dan menurunkan panas dari radiasi matahari pada siang hari. Bangunan diletakkan pada area privat yang jauh dari jalan utama dan terlindung di balik rimbun pohon-pohon eksisting di dalam tapak. Perletakan fungsi hunian utamanya pada sisi Utara, sudut Barat dan Selatan dari tapak.

3. Penerapan pola sirkulasi dan tata massa radial di dalam tapak untuk menghubungkan fungsi-fungsi privat, semi privat/servis, dan privat (hunian) dengan seefisien mungkin. Ruang-ruang bersama yang menunjang interaksi sosial seperti taman, area bermain, dan lapangan olahraga berada di tengah-tengah tapak yang dapat diakses dengan mudah dari segala arah.

4. Pengaturan massa bangunan dengan pola zig-zag yang memungkinkan ruang untuk ventilasi dan pencahayaan alami pada tiap unit kontainer, serta mengoptimalkan terciptanya ruang-ruang positif bagi 
penghuninya untuk berinteraksi sosial.

5. Struktur bangunan berbentuk grid yang sederhana dan stabil yang juga efisien dalam pembangunan serta menciptakan struktur berpanggung untuk menunjang sirkulasi udara di dalam tapak sekaligus mengurangi tutupan lahan oleh bangunan.

6. Pengolahan material kontainer bekas sehingga menjadi nyaman untuk ditinggali melalui teknik penginsulasian menggunakan material glass wool dan vapor retarder pada dinding, lantai dan atapanya. Jenis container yang digunakan adalah kontainer berstandardisasi ISO jenis High Cube setinggi dengan modul 20 kaki dengan tinggi sekitar 2,896 meter. Ketinggian ruang dalam yang dicapai oleh jenis container ini dinilai yang paling humanis sebab sesuai dengan standar ketinggian plafond minimum SNI yaitu sebesar 2,40 meter.

\section{DAFTAR PUSTAKA}

Bernardo, L. F., L. A Oliveira, M. C Nepomuceno, \& J. M Andrade. 2013. Use of refurbished shipping containers for the construction of housing buildings: details for the structural project. Journal of Civil Engineering and Management, 19(5), 628-646.

[BPS] Badan Pusat Statistik Kota Makassar. 2017. Makassar Dalam Angka 2017. Makassar.

Carissa Laurentia \& Nadia Nathania. 2019. "Effect of Implementing Modular Container Structure Towards The Roomand Corridor Quality in Chara Hotel". Risa Jurnal Vol.03 No.01 Januari 35-50.

Fisu AA. 2016. "Analisis dan Konsep Perencanaan Kawasan Pelabuhan Kota Penajam sebagai Pintu Gerbang kab. Penajam Paser Utara, Kalimantan Timur”. Jurnal Pena Teknik Vol.01 No.02 September 2016. 125136.

Fisu AA. 2016 Potensi Demand Pengembangan Kanal Jongaya \& Panampu Sebagai Moda Transportasi (Waterway) di Kota Makassar. 2016. JMTranslog 3 (3), 285-298.

Fitrianto Ekan, Ashadi, Prayogi Lutfi. 2017. "Penerapan Konsep Reuse pada Hunian dan Perkantoran di Kawasan Bongkar Muat Pelabuhan”. Jurnal Arsitektur Purnarupa Vol.01 No.01 Maret 2017 29-32.

Haq Zahrah Dhiya'ul, Firmansyah Rangga, dan Sudarisman Irwan. 2017. "Perancangan Interior Sekolah Anak Jalanan Master Indonesia di Kawasan Terminal Terpadu Kota Depok Dengan Pendekatan Desain Berkelanjutan Biomimicry". E-Proceeding of Art \& Design Vol.04 No.01 April 2017 102-113.

Herman, Asnawi. 2016. "Preferensi Bermukim Tenaga Kerja Kawasan Industri Makassar”. Jurnal Pembangunan Wilayah dan Kota Biro Penerbit Planologi Undip, Vol. 12 (3), 293-302.

Hidayat Adrianto \& Fisu Amiruddin Akbar. 2019. "Konsep Arsitektur Panti Rehabilitasi Ketergantungan Narkotika \& Psikotropika Di Makassar, Pendekatan Arsitektur Postmodern Historiscm.” INA-Rxiv. May 27. Doi:10.31227/Osf.Io/E4gtu.

Ismail, M., K. M Al-Obaidi, A. M Abdul Rahman. \& M. I Ahmad. 2015. Container Architecture in the HotHumid Tropics: Potential and Constraints. International Conference on Environmental Research and Technology, 142-149.

Kamarazaly, Myzatul Aishah, et al. 2017. A Feasibility Study on Container Construction in Malaysia. Journal of Built Environment, Technology and Engineering, Vol. 3, 110-119.

Kumara Boris \& Kusumarini Yusita. 2015. "Perancangan Refunction Container Sebagai Modular Retail di Surabaya". Jurnal Intra Vol.03 No.01 2015 29-32.

Kurniasih, Sri. 2019. Passive Cooling Sebagai Pengudaran Alami Pada Rumah Tinggal. Jurnal Fakultas Teknik ARSITRON Vol. 9 (1)

Latifah, Nur Laela, Erwin Yuniar Rahadian. 2018. Strategi Green Building untuk Optimalisasi Penghematan Energi Operasional Bangunan terkait Rancangan Ventilasi dan Pengkondisian Udara pada Gedung Kantor Pengelola Bendungan Sei Gong - Batam. Seminar Nasional ITENAS 2018, A7-A12.

Mala, Yordan Perwi, Josephus I. Kalangi, Fabiola B. Saroinsong. 2018. Pengaruh Ruang Terbuka Hijau Terhadap Iklim Mikro dan Kenyamanan Termal Pada 3 Lokasi di Kota Manado. Jurnal Ilmu Pertanian Eugenia, Vol. 24 (2), 52-63.

Mahira Eka Diana \& Hignasari Virginayoga. 2018. "Konsep Mandala Pada Rancangan Limbah Kontainer Untuk Hunian Sementara Korban Bencana Alam Bali”. Vitruvian Jurnal Arsitektur, Bangunan dan Lingkungan Vol07 No.02 Februari 2018 77-86.

Mariana, Yosica. 2014. Pemanfaatan Ruang Terbuka Hijau di Rumah Susun Studi Kasus: Rumah Susun Kebon Kacang dan Bendungan Hilir I. ComTech: Computer, Mathematics and Engineering Applications, Vol 5 (2), 851-859

Nandini, Widya, Sari Wahyuni. 2019. Analisa Gender dan Pentingnya Kondisi Psychological Wellbeing Buruh Di Tempat Kerja. Jurnal Riset Manajemen Sains Indonesia (JRMSI), Vol 10 (1), 71-95. 
Prajogo Maria Valenciana Utari \& Tedjokoesoemo. 2015. "Perancangan Interior Kontainer Sebagai Sarana Edukasi di Rusun Sombo Surabaya". Jurnal Intra Vol.03 No.02 551-562.

Prasetyo Lucky, Tobing Rumiati \& Budiyuwono Hartato. 2018. "Konsep Ekologis dan Budaya pada Perancangan Hunian Paska Bencana di Yogyakarta". Jurnal Teknik Arsitektur Arteks Vol.02 No.02 Juni 2018 125-136.

[PERMEN] Peraturan Menteri Pekerjaan Umum Nomor 05 Tahun 2007 Tentang Pedoman Teknis Pembangunan Rumah Susun Sederhana Bertingkat Tinggi

Septianto Egi, Dwi Handono P, Rahman Arief H, Susetyo Dimastian. 2015. "Aplikasi Modul Kontainer Terhadap Desain Ruang pada Bangunan Poli Gigi dan Taman Baca Amin di Batu Malang". Jurnal Reka Karsa No.01 Vol.03 1-11.

Susanto, Lianggono. 2014. Eksplorasi Terapan Refunctioned Container Menjadi Ruang-Bangunan Taman Baca Amin di Batu, Jawa Timur. Dimensi Interior, Vol. 12 (1), 23-30.

[SNI] Tata Cara Perencanaan Lingkungan Perumahan di Perkotaan. SNI 03-1733-2004.

[UU] Undang-Undang Nomor 16 Tahun 1985 Tentang Rumah Susun.

Wunas, Shirly, Venny Veronica Natalia. 2015. Pembangunan Infrastruktur Transportasi di Kota Makassar. Jurnal Transportasi, Vol. 15 (3), 169-178. 